\title{
Regional Potential Analysis Based on Agricultural Commodities of Food Crops and Their Contribution to the Economy in the Karangsambung-Karangbolong Geopark Area, Indonesia: A Location Quotient Approach
}

\author{
Rika Harini $^{*}$, Rina Dwi Ariani, Bowo Susilo and Evita Hanie Pangaribowo \\ Faculty of Geography, Universitas Gadjah Mada, Indonesia
}

\begin{abstract}
The Karangsambung-Karangbolong Geopark Area is located in Kebumen, one of the districts with the highest poverty rate in the Province of Jawa Tengah, Indonesia. A regional economy can be improved by optimizing existing potentials in the agricultural sector, especially food-crop commodities. This research set out to determine 1) the basic or leading food crops per sub-district, (2) the relatively potential food crops to maintain, and 3) the rating of the carrying capacity of facilities in maintaining relatively potential commodities. This research used secondary data from the BPS-Statistics Indonesia, such as food-crop commodity production and infrastructure conditions. It employed the Location Quotient (LQ) method, the LQ's strength criteria analysis and scalogram. The analysis results showed that each sub-district has distinct basic commodities, but rice, cassava and sweet potatoes were the best potential commodities to develop. The Karangsambung-Karangbolong Geopark Area is equipped with facilities and infrastructure with fairly good to good carrying capacities supporting the development of the three commodities.
\end{abstract}

\section{Introduction}

Kebumen is the district with the highest poverty rate in the Province of Jawa Tengah, Indonesia (16.82\%), far above the average poverty rate of the province $(10.8 \%)$ [1]. Poverty has a negative and significant effect on economic growth [2]. According to the updated data in 2020 by BPS-Statistics Indonesia, the district's economic growth is $-1.46 \%$ [3]. Poverty reportedly results in a lack of investment and physical capital, leading to lower economic growth. The inadequate investment is attributed to sub-standard human and natural resource management [4], [5].

Regional economic conditions are dependent on several factors, including the potential of natural resources owned. Regions rich in natural resources are believed to have the capacity to achieve greater economic growth than ones with less natural resources [6], [7], [8], [9], [10]. However, the failure to appropriately manage such abundance will bring about the resource curse hindering economic growth [11], [12] or even causing negative economic growth. Therefore, the resource curse must be overcome with regional economic development through joint activities between the government and the local community by optimally utilising and managing resources to stimulate economic growth [13].

\footnotetext{
* Corresponding author: rikaharini@ugm.ac.id
}

Many factors play pivotal roles in determining regional economic growth, including natural resources, human resources, industrialisation and technological innovation. Technological innovation can strengthen the positive impact of several variables that affect economic growth and help to reduce negative impacts, especially the environmental impact [12]. Agriculture, forestry and fishery are sectors with the largest share contributing to the regional economy of Kebumen District, i.e., 21.79\% [14]. Based on these data, it can be concluded that the three sectors are the basis of regional economic development in Kebumen.

The development of regional potentials through a commodity approach, especially food-crop agricultural commodities, is not perceived merely in terms of economy but also facility supporting such commodity development. According to Nikijuluw (2013), the economic potential in a region becomes insignificant for the regional economic development if there is an absence of optimal development and utilisation. The economic base theory addresses how to overcome various problems concerning agricultural commodity-based potentials in regional development by focusing on the demand for goods and services from other regions as the main determinants of economic growth. This theory also identifies a region's basic or non-basic development sectors [18], [19]. 
This research was designed to determine 1) the basic or leading commodities, 2) the potential commodities to maintain and 3) the carrying capacity

\section{Methodology}

This research was conducted in the KarangsambungKarangbolon Geopark Area, Kebumen District, the Province of Jawa Tengah, Indonesia. This location was selected purposively based on two considerations: its natural resources potential and its socioeconomic condition as the district with the highest poverty rate in the province. The research used secondary datai.e., details and information not directly obtained from the sources [18] — collected from several publications issued by the BPS-Statistics Indonesia for Kebumen District.

The first research objective was analysed using the Location Quotient method to determine the potential of economic activity of particular agricultural commodities to indicate basic and non-basic sectors by comparing the capabilities of the same commodities in a wider area (see Equation 1) [19]:

$$
L Q=\frac{(v i / v t)}{(V i / v t)}
$$

Where:

LQ = LQ (ratio value) of food-crop commodities in each sub-district

$\mathrm{vi}=$ Average production of each food-crop commodity in Sub-district $i$

$\mathrm{vt}=$ Total average production of overall food-crop commodities in Sub-district i

$\mathrm{Vi}=$ Average production of each food-crop commodity in Kebumen District

$\mathrm{Vt}=$ Total average production of overall food-crop commodities in Kebumen District

The proviso of this method is that if $\mathrm{LQ}>1$, it means that the commodity becomes the basic or leading commodity; the results can be used to meet the region's needs and those of other regions. If $L Q<1$, it indicates that the commodity is considered non-basic or does not have advantages. The production of such commodity cannot be used to meet the region's needs; thus, it requires supplies from other regions. Meanwhile, if $\mathrm{LQ}=1$, it means that the commodity is considered non-basic and does not have advantages in which it is still capable of meeting the needs of the region but is unable to provide supplies to other regions in need [20], [21].

The second research objective was analysed based on the LQ's strength criteria. The analysis criterion is of facilities supporting the leading commodities. For this purpose it employed Location Quotient (LQ), the analysis of the LQ's strength criteria and scalogram. that food-crop commodities that occupy the most base areas are relatively potential commodities to maintain. The basis of the analysis is sub-district; the more subdistricts categorised as the basis for a certain commodity, the more reliable it is categorised as relatively potential sectors to develop.

The third research objective was analysed using a scalogram. The advantage of the analysis is that it is able to score the facilities owned by each sub-district [22]. Further, according to Budiharsono (2001), the scalogram analysis categorises the carrying capacity of facilities into three, namely:

1. Category 1 means that the carrying capacity of facilities in the region is good

2. Category 2 means that the carrying capacity of facilities in the region is relatively good

3. Category 3 means that the carrying capacity of facilities in the region is poor.

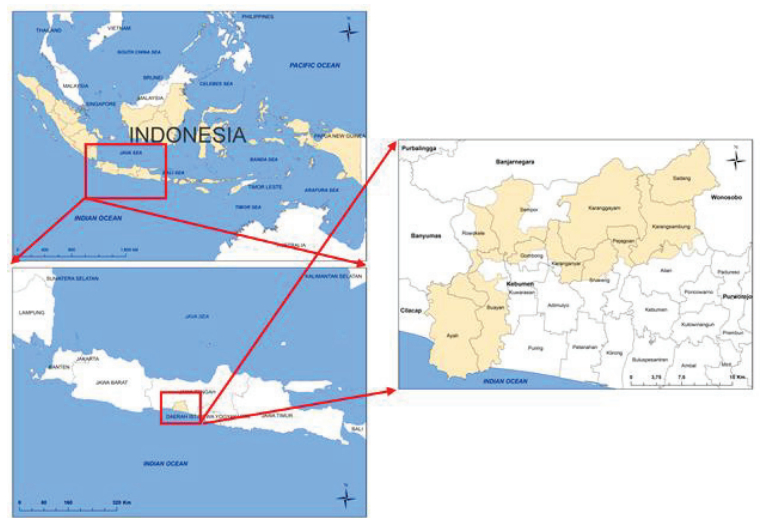

Fig. 1. Research Site Map

\section{Results and discussion}

\subsection{Basic Food Crops in the Karangsambung- Karangbolong Geopark Area}

The main policy that needs implementation in regional economic development was to optimally arrange regional development priorities based on the region's potential. These potentials vary across regions; hence, the dominant leading potential needs to be determined [24].

The Location Quotient approach was used to identify basic or leading food-crop commodities in the Karangsambung-Karangbolong Geopark Area by calculating their LQs. LQ $>1$ is a criterion for basic commodities, while LQ $<1$ is for non-basic commodities. Table 1 summarises the basic food-crop commodities in the Geopark area. 
Table 1. Basic Food Crops in the Karangsambung-Karangbolong Geopark Area in 2009-2018

\begin{tabular}{|c|c|c|}
\hline NO & $\begin{array}{c}\text { FOOD-CROP } \\
\text { COMMODITIES }\end{array}$ & SUB-DISTRICTS \\
\hline 1. & Rice & Ayah, Buayan, Rowokele, Gombong, Pejagoan, Alian \\
\hline 2. & Maize & - \\
\hline 3. & Soybeans & Ayah, Buayan, Rowokele, Gombong, Pejagoan \\
\hline 4. & Cassava & Sempor, Karanganyar, Karanggayam, Sruweng, Karangsambung, Sadang \\
\hline 5. & Sweet potatoes & Buayan, Sempor, Karanganyar, Sruweng, Pejagoan, Karangsambung \\
\hline 6. & Groundnuts & - \\
\hline 7. & Green beans & Buayan, Sempor, Gombong, Karanganyar, Sruweng \\
\hline
\end{tabular}

Source: Secondary data analysis (2021)

The analysis results in Table 1 indicate that the sub-districts in the Karangsambung-Karangbolong Geopark Area had different basic food crops owing to their respective characteristics, e.g., land fertility, geographical location, human resources and existing facilities and infrastructure. Rice, cassava and sweet potatoes were the basic commodities in most subdistricts. Basic agricultural commodities are commodities that have great potential to be marketed outside the economic boundaries of the production area because of the excess yield amounts even after being used to meet the region's needs. Therefore, they potentially provide incomes for the region and are more feasible to develop than non-basic commodities.
Meanwhile, maize and groundnuts were non-basic commodities in the entire Geopark area. In conclusion, not all commodities in a region can be used as leading commodities. It requires distinct management of agricultural resources in each region.

The bar chart in Figure 1 shows the LQs of each observed commodity in the KarangsambungKarangbolong Geopark Area. Soybeans, cassava and sweet potatoes were commodities with LQ $>1$, while rice, maize and groundnuts had LQ $<1$. The remainder, green beans, was the only commodity showing $\mathrm{LQ}=1$.

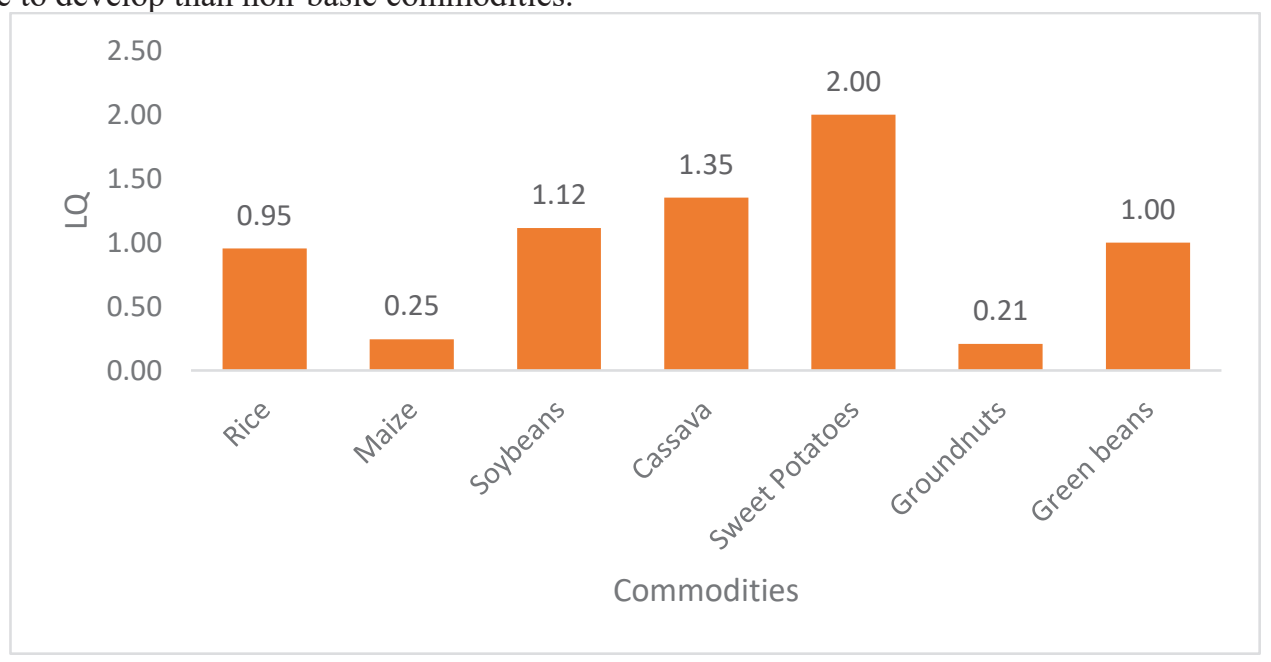

Fig. 2 Average Location Quotients of Food-Crop Commodities in the Karangsambung-Karangbolong Geopark Area

The commodity with the highest LQ (2.00) was sweet potatoes, indicating that this food crop has been able to meet the needs in the Geopark area while also providing supplies to other regions. Other food crops categorised as basic or leading commodities were cassava (1.35) and soybeans (1.12). Leading commodities are commodities with added values and large production that can increase regional economic growth. They also have substantial multiplier effects on other economic activities, the development of the surrounding areas and other commodities with high market demand [25]. The food crops that were not categorised as basic commodities were rice, maize, groundnuts and green beans $(\mathrm{LQ} \leq 1)$. These results indicate that the first three commodities have not been able to meet the region's needs and thereby require supplies from other regions $(\mathrm{LQ}<1)$, while green beans have been able to meet the region's needs despite but unable to provide supplies to other regions $(\mathrm{LQ}=1)$.

The selection of the basic commodities can change at any time, depending on the production level 
during the analysis. Suppose during the analysis a specific commodity is selected or determined as a basic or non-basic commodity and the government adopts this selection and makes efforts to develop and increase its production by adopting technology and expanding land, it is highly likely that the commodity changes its status (from non-basic to basic and vice versa) in the following year. Agricultural production is generally influenced by several factors, including nature, labour, capital and management [26]. The development of basic or leading commodities is enforced with the issuance of Law Number 18 of 2012 on Food, stating that the local government has responsibility for the sustainable development of local food production in the region [27].

\subsection{Relatively Potential Food Crops to Maintain in the Karangsambung- Karangbolong Geopark Area}

The Location Quotient's strength criteria were analysed to determine the relatively potential foodcrop commodities to maintain in the KarangsambungKarangbolong Geopark Area. The idea is food-crop commodities that occupy the most base areas are relatively potential commodities to maintain at the research location. Figure 3 shows the relatively potential food-crop commodities to maintain in the Karangsambung-Karangbolong Geopark Area.

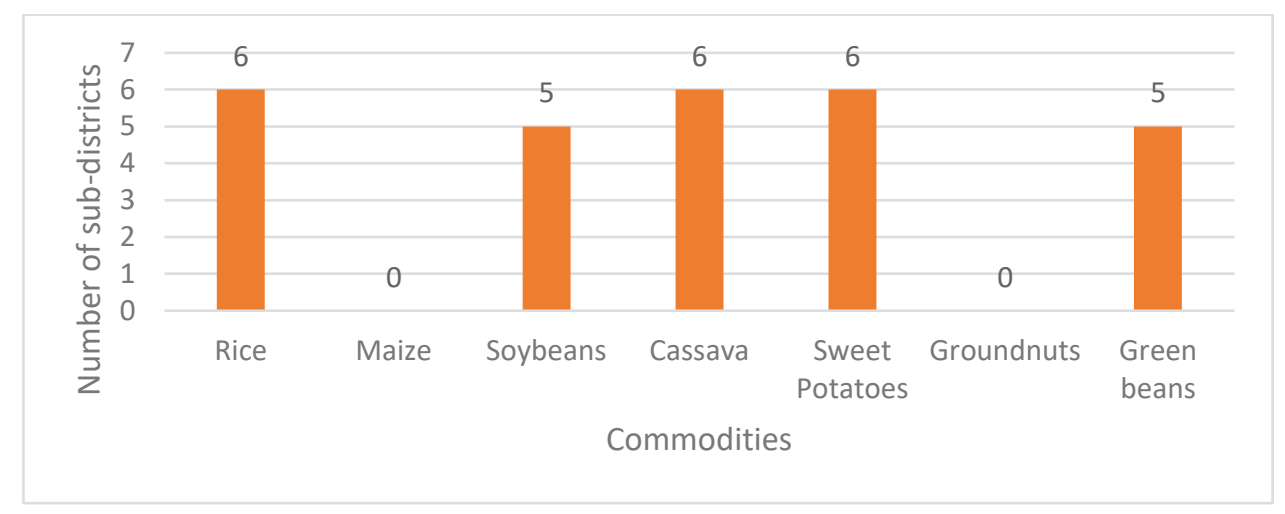

Fig. 3 Relatively Potential Food-Crop Commodities to Maintain in the Karangsambung-Karangbolong Geopark Area

Based on Figure 3, it can be seen that the relatively potential food-crop commodities to develop in the Karangsambung-Karangbolong Geopark Area were rice, cassava and sweet potatoes. These three commodities occurred as the basic food crops in six of the twelve sub-districts.

Rice was categorised as the relatively potential commodity to develop in the Geopark area. Despite its general LQ (0.95), rice became the basic commodity in six sub-districts. Some of the efforts that can be carried out to support this food crop as the leading commodity are 1) using excellent seeds, 2) reducing the use of pesticides to eradicate pests and 3) improving facilities and infrastructure.
Cassava has the potential to develop as the leading commodity because it produces higher yields than the average regional production. Some of the efforts that can be carried out to maintain it as the leading commodity are 1) disseminating information about the use of excellent seeds and 2) using cassava as raw materials for industry and animal feed.

Likewise, sweet potatoes also show the potential to develop as the leading commodity since the crop's average regional production is lower than that of the Geopark area. Sweet potatoes can continue to have said potential by 1) disseminating information about the use of excellent seeds and 2) using sweet potatoes as raw materials for snacks. 

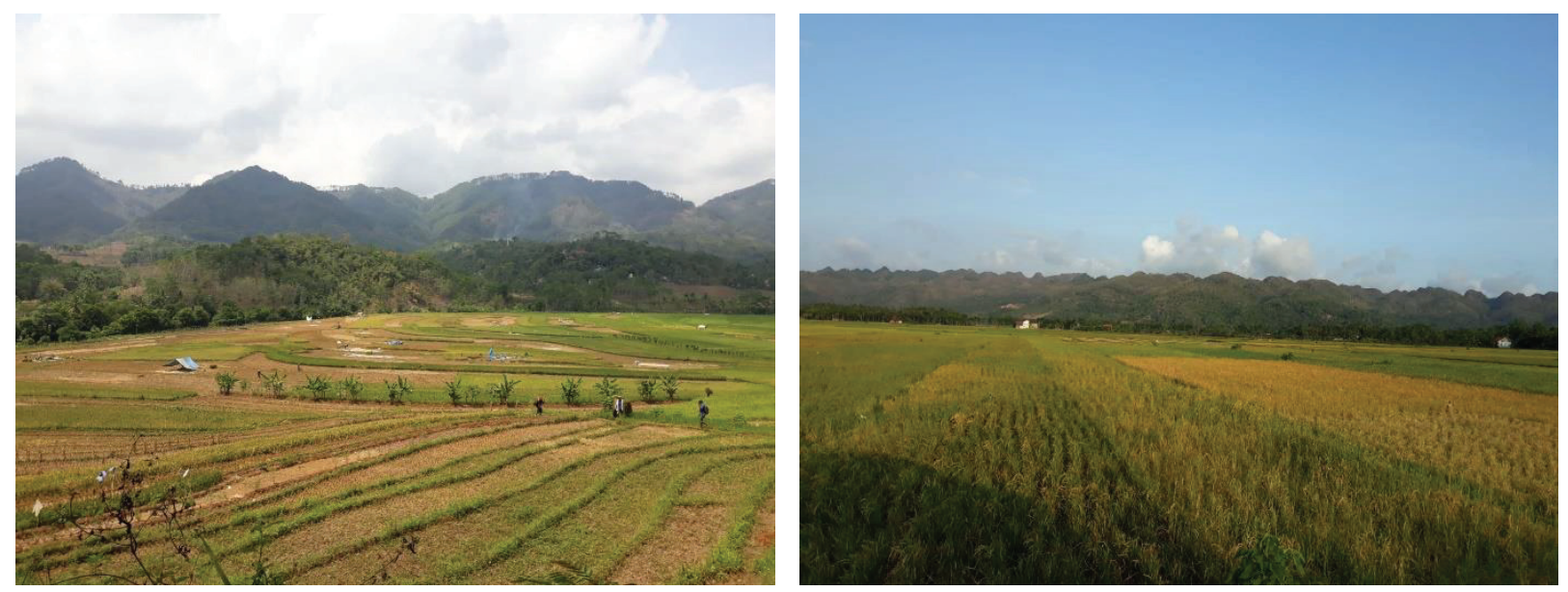

Fig. 4 Agricultural Land in the Karangsambung-Karangbolong Geopark Area

The existence of leading agricultural commodities in the Karangsambung-Karangbolong Geopark Area will certainly improve the regional economy since the agricultural sector is the mainstay of livelihood in the rural areas. It can absorb a greater workforce than other sectors, provide foods, raw materials and capital and survive in times of crisis [28], [29]. With leading commodities, the agricultural sector also plays a crucial role in the regional economy as it 1) has abundant natural resources, 2) shores up regional income and 3 ) becomes the livelihood that many people depend on [30].

\subsection{Rating of the Carrying Capacity of the Facilities to Maintain Relatively Potential Commodities in the Karangsambung- Karangbolong Geopark Area}

According to Novrilasari (2008), the carrying capacity of facilities in a region can affect regional development [31]. Areas with good facilities will be more developed than those with poor facilities. The relatively potential food-crop commodities to develop in the Geopark area are undoubtedly supported by sufficiently available facilities to sustain regional economic activities.

The centre of growth and service in a region will provide benefits to it. According to Sidik (2016), the scalogram is a region's concentration analysis that identifies key facilities with a hierarchy and characters typical of a developing region [32]. The scalogram analysis was used to rate the regional development in terms of facilities that supported food-crop commodities with relative potential for being developed in the Geopark area. The facilities include the length of the road and the distance to the city centre, markets and irrigation. Table 2 shows the distribution of the carrying capacity of facilities to maintain the relatively potential commodities in the Karangsambung-Karangbolong Geopark Area.

Table 2. Distribution of the Carrying Capacity of Facilities to Maintain the Relatively Potential Commodities in the Karangsambung-Karangbolong Geopark Area

\begin{tabular}{lccrrrrr}
\hline \multicolumn{1}{c}{ Sub-districts } & $\mathbf{a}$ & $\mathbf{b}$ & $\mathbf{c}$ & $\mathbf{d}$ & Total Scores & Categories \\
\hline Ayah & 3 & 1 & 3 & 1 & 8 & 2 \\
Buayan & 2 & 1 & 3 & 2 & 8 & 2 \\
Rowokele & 2 & 1 & 2 & 1 & 6 & 2 \\
Sempor & 3 & 2 & 1 & 3 & 9 & 1 \\
Gombong & 1 & 2 & 2 & 3 & 8 & 2 \\
Karanganyar & 1 & 2 & 2 & 1 & 6 & 2 \\
Karanggayam & 3 & 1 & 1 & 1 & 6 & 2 \\
Sruweng & 1 & 3 & 2 & 3 & 8 & 2 \\
Pejagoan & 1 & 3 & 1 & 3 & &
\end{tabular}




\begin{tabular}{|c|c|c|c|c|c|c|}
\hline Sub-districts & $\mathbf{a}$ & $\mathbf{b}$ & c & d & Total Scores & Categories \\
\hline Alian & 1 & 3 & 2 & 2 & 8 & 2 \\
\hline Karangsambung & 2 & 2 & 1 & 1 & 6 & 2 \\
\hline Sadang & 2 & 1 & 1 & 2 & 6 & 2 \\
\hline
\end{tabular}

Source: Secondary data analysis, 2021

Notes: a: road length $(\mathrm{km})$

b: distance to the city centre $(\mathrm{km})$

c: market (unit)

d: irrigation

Based on Table 2, it can be inferred that the highest total score of facilities from all sub-districts in the Geopark area was nine (9), and the lowest was six (6). The score marks the carrying capacity of facilities to maintain relatively potential food-crop commodities. Sub-districts with a total score of 3-5 were included in Category 3 (poor), while ones with a total score of 6-8 were in Category 2 (relatively good). Lastly, those with a total score of 9-12 fell into Category1 (good).

Sub-districts in Category 1 had facilities with a good carrying capacity to support the relatively potential commodities in the KarangsambungKarangbolong Geopark Area. There were two subdistricts included in this category: Sempor and Sruweng. Sub-districts in Category 2 had a relatively good carrying capacity of facilities to maintain the relatively potential commodities. There were ten subdistricts included in this category: Ayah, Buayan, Rowokele, Gombong, Karanganyar, Karanggayam, Pejagoan, Alian, Karangsambung and Sadang. Subdistricts that fell into Category 3 had facilities with a poor carrying capacity to maintain the relatively potential commodities. However, none of the twelve sub-districts in the Geopark area was included in this category.

Rice, cassava and sweet potatoes are potential commodities to maintain in the Geopark area since these three food crops were identified as the basic commodities in most sub-districts. Also, the subdistricts that became the basis for these commodities are located in the Geopark area and have a good carrying capacity of facilities to support farming activities for these commodities.

\section{Conclusion}

The sub-districts in the KarangsambungKarangbolong Geopark Area have different basic food-crop commodities based on their respective geographical conditions. Rice, cassava and sweet potatoes are concluded as the basic and relatively potential commodities in most sub-districts. Ten subdistricts located in the Geopark area have a relatively

good carrying capacity of facilities, and two of which have a good carrying capacity to support the relatively potential commodities.

\section{References}

1. Databoks (2020, 28 Maret). Wilayah dengan Tingkat Kemiskinan Tertinggi di Jawa Tengah". Diakses $31 \quad$ Mei 2021, dari https://databoks.katadata.co.id/datapublish/2020/0 3/28/wilayah-dengan-tingkat-kemiskinantertinggi-di-jawa-tengah/

2. H. Siregar dan D. Wahyuniarti, Dampak Pertumbuhan Ekonomi Terhadap Penurunan Jumlah Penduduk Miskin, Jurnal Ekonomi Politik dan Keuangan. (2007) 54-56

3. DPRD Kabupaten Kebumen (2021, 29 Maret). LKPJ Bupati Tahun 2020: Pertumbuhan Ekonomi Minus 1,4 Persen, Pendapatan Daerah Tercapai 103 Persen. Diakses 31 Mei 2021, dari https://dprd-kebumenkab.go.id/2021/03/29/1kpjbupati-tahun-2020-pertumbuhan-ekonomi-minus14-persen-pendapatan-daerah-tercapai-103persen/

4. R. Breuning and O. Majeed, Inequality, poverty and economic growth, International Economics, 161 (2020) 83-99

5. M. Ravallion, Why Don't We See Poverty Convergence?, American Economic Review, 102, 1 (2012) 504-524

6. M. Asrif, K. B. Khan, M. K. Anser, A. A. Nassani, M. M. Q. Abro and K. Zaman, Dynamic interaction between financial development and natural resources: Evaluating the 'Resource curse' hypothesis, Resources Policy, 65 (2020), 101566

7. Z. Khan, M, Ali, L. Jinyu, M. Shahbaz and Y. Siqun, Consumption-based carbon emissions and trade nexus: Evidence from nine oil exporting countries, Energy Economics, 89 (2020), 104806

8. Z. Khan, M. Hussain, M. Shahbaz, S.Yang and Z. 
Jiao, Natural resource abundance, technological innovation, and human capital nexus with financial development: A case study of China, 65 (2020), 101585

9. R. A. Dwumfour and M. Ntow-gyamfi, Natural resources, financial development and institutional quality in Africa: Is there a resource curse?, Resources Policy, 59 (2018) 411-426

10. S. Rahim, M. Murshed, S. Umarbeyli, D. Kirikkaleli, M. Ahmad, M. Tufai and S. Wahab, Do natural resources abundance and human capital development promote economic growth? A study on the resource curse hypothesis in Next Eleven countries, Resources, Environment and Sustainability, 4 (2021) 100018

11. K. Ahmed, M. K. Mahalik and M. Shahbaz, Dynamics between economic growth, labor, capital and natural resource abundance in Iran: An application of the combined cointegration approach, Resources Policy, 49 (2016) 213-221

12. Q. Shao, Nonlinear effects of marine economic growth and technological innovation on marine pollution: Panel threshold analysis for China's 11 coastal regions, Marine Policy, 121 (2020) 104110

13. Subandi, Ekonomi Pembangunan, Cetakan Kesatu, Alfabeta, Bandung, 2011.

14. Badan Pusat Statistik, Kabupaten Kebumen dalam Angka 2021, BPS, Kebumen, 2021.

15. M. L. Jhingan, Ekonomi Pembangunan dan Perencanaan, Raja Grafindo Persada, Jakarta. 2007.

16. L. Arsyad, Ekonomi Pembangunan, Edisi Kelima, UPP STIM YKPN, Yogyakarta, 2015.

17.J.B. Nikijuluw, Analisis Sektor Ekonomi Unggulan Kabupate/Kota di Provinsi Maluku, Cita Ekonomika, 7, 2 (2013) 196-303.

18. L. Muta'ali, Teknik Analisis Regional untuk Perencanaan Wilayah Tata Ruang dan Lingkungan, BPFG, Yogyakarta, 2015

19. E. P. Yuendini, I. N. Rachmi, N. N. A. Puspitasari, R. Harini dan M. A. F. Alfana, Analisis Potensi Ekonomi Sektor Pertanian dan Sektor Pariwisata di Provinsi Bali Menggunakan Teknik Analisis Regional, Jurnal Geografi, 16, 2 (2019) 128-136

20. Sugiyono, Metode Penelitian Kuantitatif dan R \& D, Alfabeta, Bandung, 2016.

21. Bendavid, Regional and Local Economic Analysis for Practionersm, Praeger Publisher Inc, New
York, 1991.

22. B. Oksatriandhi, E. B. Santoso, Identifikasi Komoditas Unggulan di Kawasan Agropolitan Kabupaten Pasaman, Jurnal Teknik POMITS, 3, 1 (2014) 8-11

23. N. Baladina, R. Anindita, R. Iskandar, Sukardi, Identifikasi Potensi Komoditas Pertanian Unggulan dalam Penerapan Konsep Agropolitan di Kecamatan Poncokusumo, Jurnal AGRISE, 13, 1 (2013) 30-41

24. Suning, Identifikasi Sektor Ekonomi Basis (Unggulan) dan Hierarki Pusat Pelayanan Berdasarkan Tingkat Kemampuan Fasilitas Dalam Rangka Pengembangan Wilayah (Studi Kecamatan Kasiman dan Kecamatan Padangan Kabupaten Bojonegoro), Teknik Waktu, 9, 2 (2011) 25-33.

25. S. Budiharsono, Teknik Analisis Pembangunan Wilayah Pesisir dan Lautan, Pradnya Pramita, Jakarta, 2001.

26. Sjafrijal, Perencanaan Pembangunan Daerah Dalam Era Otonomi Daerah, Rajawali Pers, Jakarta, 2014.

27. Soekartawi, Agribisnis Teori dan Aplikasinya, Raja Grafindo Persada, 2005.

28. R Harini dan B. Susilo, Kajian Spasial Perubahan Iklim Terhadap Produksi Pertanian, Jurnal Agribisnis, 1, 1 (2017) 14-20

29. D. Novrilasari, Analisis Sektor Unggulan dalam Meningkatkan Perekonomian dan Pembangunan Wilayah Kabupaten Kuantan Singingi, Institut Pertanian Bogor, Bogor, 2008.

30. R. Rosyanti, Analisis Pendapatan Usaha Tani, Pemasaran dan Nilai Tambah Ubi Kayu, Agribisnis, IPB Bogor, 2011

31. Todaro, Pembangunan Ekonomi Dunia Ketiga, Erlangga, Jakarta, 2011

32. R. Harini, C. Ramadhan and F. S. Rudi, Agricultural resource potential for improving food security and community welfare in Penimbun Village, Karanggayam, Kebumen, Central Java, IOP Conference Series: Earth and Environmental Science, 451 (2020) 012041

33. Undang-Undang Republik Indonesia Nomor 18 Tahun 2012 tentang Pangan

34. J. Sidik, Keragaan Relatif dan Karakteristik Perkembangan Kecamatan di Kabupaten Bangkalan, Media Trend, 11, 1 (2016) 20-34. 